\title{
A Study of the Effect of Djurliete, Bornite and Chalcopyrite during the Dissolution of Gold with a Solution of Ammonia-Cyanide
}

\author{
Guy Deschênes ${ }^{1 *}$, Hai Guo ${ }^{2}$, Chen Xia ${ }^{1}$, Allen Pratt ${ }^{1}$, Mike Fulton ${ }^{1}$, Yeonuk Choi ${ }^{3}$ and \\ Judith Price $^{1}$
}

1 CanmetMining, 555 Booth Street, Ottawa, Ontario K1A 0G1, Canada; E-Mails: cxia@ nrcan.gc.ca (C.X.); apratt@nrcan.gc.ca (A.P.); michaelfltn685@gmail.com (M.F.); Judith.Price@NRCan-RNCan.gc.ca (J.P.)

2 Eldorado Gold Corporation, 1188-550 Burrard Street, Vancouver, BC V6C2B5, Canada;

E-Mail: Hai.Guo@cn.eldoradogold.com

3 Barrick Gold Corporation, 161 Bay Street, Toronto, Ontario M5J2S1 Canada;

E-Mail: ychoi@barrick.com

* Author to whom correspondence should be addressed; E-Mail: gdeschen@nrcan.gc.ca; Tel.: +1-613-992-0415; Fax: +1-613-947-1200.

Received: 25 July 2012; in revised form: 28 September 2012 / Accepted: 18 October 2012 / Published: 20 November 2012

\begin{abstract}
The high solubility of copper sulphide minerals is an issue in the cyanidation of gold ores. The objective of this study was to quantify the effect of individual copper sulphide minerals on the Hunt process, which showed advantages over cyanidation. High purity djurleite, bornite and chalcopyrite, with a $\mathrm{P}_{70}$ of 70-74 microns, were mixed with fine quartz and gold powder (3-8 micron) to obtain a copper concentration of $0.3 \%$. The ammonia-cyanide leaching of slurry with djurleite proved to be more effective than cyanidation; producing comparable extraction of gold (99\%), while reducing the cyanide consumption from 5.8 to $1.2 \mathrm{~kg} / \mathrm{t} \mathrm{NaCN}$. Lead nitrate improved the Hunt leaching. The lower cyanide consumption is associated to a significant reduction of copper dissolved. XPS surface analysis of djurleite showed that lead nitrate favored the formation of $\mathrm{Cu}(\mathrm{OH})_{2}$ species. Lead was also detected on the surface (oxide or hydroxide). Sulphide and copper compounds (cyanide and sulphide) were reaction products responsible for inhibiting the dissolution of gold. Lead nitrate added in the Hunt leaching of bornite produced 99\% gold extraction. Surface reaction products were similar to djurleite. The cyanide
\end{abstract}


consumption $(\sim 4.4 \mathrm{~kg} / \mathrm{t} \mathrm{NaCN})$ was not reduced by the addition of ammonia. Cyanidation of chalcopyrite showed a lower consumption of cyanide $0.33 \mathrm{~kg} / \mathrm{t} \mathrm{NaCN}$ compared to $0.21 \mathrm{~kg} / \mathrm{t} \mathrm{NaCN}$ for Hunt. No significant interferences were observed in gold leaching with a slurry containing chalcopyrite.

Keywords: gold; cyanide; ammonia, copper minerals; chalcopyrite; bornite; djurleite

\section{Introduction}

Australian organizations invested considerable efforts in the development and application of the ammonia-cyanide leaching (Hunt process) for the extraction of gold from ores containing a high concentration of copper in the 1990s [1-6] and 2000s [7,8]. Early work on leaching of the Buzwagi copper-bearing ores demonstrated the potential of the Hunt process in terms of gold extraction, consumption of cyanide and copper dissolution [9]. It was found that the control of cyanide concentration is a key parameter. High cyanide dosage improves the leaching of gold by providing more free cyanide. Meanwhile, the dissolution of copper minerals is enhanced. A high ratio of cyanide to ammonia jeopardizes the Hunt mechanisms due to the increased stability of $\mathrm{Cu}(\mathrm{CN})_{3}{ }^{2-}$. Therefore, the optimum leaching conditions have to avoid high cyanide concentrations and to provide control the ratio of cyanide and ammonia within a narrow range.

There is limited information on the behavior of individual copper mineral in the Hunt process. In this paper, the effect of chalcopyrite $\left(\mathrm{CuFeS}_{2}\right)$, djurleite $\left(\mathrm{Cu}_{31} \mathrm{~S}_{16} \mathrm{Cu}_{1.94} \mathrm{~S}\right)$ and bornite $\left(\mathrm{Cu}_{5} \mathrm{FeS}_{4}\right)$, which are among the most common copper sulphide minerals associated to gold ores, are investigated.

\section{Experimental Section}

\subsection{Material}

A synthetic gold ore was produced by mixing gold grains at a concentration of $10 \mathrm{~g} / \mathrm{t}$ (3-8 micron) with 200 grams of quartz fines ( $\mathrm{P}_{99}$ of $70-74$ micron) and about $0.3 \%$ weight of copper as one of the following three natural copper sulphides minerals: djurleite, chalcopyrite and bornite with 93.8\%, 99.9\% and $96.85 \%$ purity, respectively. The mineralogical and elemental compositions of these minerals are shown in Tables 1 and 2. Djurleite $\left(\mathrm{Cu}_{31} \mathrm{~S}_{16}\right)$ has a chemical composition which is very similar to chalcocite $\left(\mathrm{Cu}_{2} \mathrm{~S}\right)$. The main differences between this mixture of quartz and gold and a real gold ore are the all the gold is free for leaching and the degree of purity of the mixture.

The minerals were ground to a $\mathrm{P}_{70}$ of 70-74 microns with a micro mill and stored in a desiccator in sealed plastic bags. The amount of minerals added in each test was based on the copper grade and mineral purity. The gold powder was added to ten kilograms of quartz fines, tumbled overnight to homogenize the sample and split in $200 \mathrm{~g}$ lots using a rotary separator. 
Table 1. Elemental compositions of copper sulphide minerals.

\begin{tabular}{llll}
\hline Element & Bornite (\%) & Djurleite (\%) & Chalcopyrite (\%) \\
\hline $\mathrm{Al}$ & 0.44 & 0.01 & 0.006 \\
$\mathrm{As}$ & 0.88 & bdl & $<0.003$ \\
$\mathrm{Bi}$ & 7.51 & 0.01 & $<0.003$ \\
$\mathrm{Ca}$ & 4.34 & 0.03 & $<0.07$ \\
$\mathrm{Co}$ & 0.12 & bdl & 0.02 \\
$\mathrm{Cu}$ & 67.7 & 79.7 & 33.2 \\
$\mathrm{Fe}$ & 10.8 & 0.07 & 32.2 \\
$\mathrm{~Pb}$ & 0.02 & bdl & 0.01 \\
$\mathrm{~S}$ & 26.6 & 21.8 & 34.5 \\
$\mathrm{Sb}$ & 0.01 & bdl & $<0.002$ \\
$\mathrm{Si}$ & 0.06 & 0.08 & 0.06 \\
$\mathrm{Te}$ & $\mathrm{Bdl}$ & 0.01 & $<0.008$ \\
$\mathrm{Zn}$ & 0.12 & bdl & 0.23 \\
\hline
\end{tabular}

bdl: below detection limit.

Table 2. Mineralogical compositions of copper sulphide minerals.

\begin{tabular}{ll|ll|ll}
\hline \multicolumn{2}{c|}{ Bornite } & \multicolumn{2}{c}{ Dijurleite } & \multicolumn{2}{c}{ Chalcopyrite } \\
Minerals & \% w/w & \multicolumn{1}{c}{ Minerals } & \% w/w & Minerals & \% w/w \\
\hline quartz & 0.1 & quartz & 0 & chalcopyrite & 99.9 \\
bornite & 96.8 & dijurleite & 93.8 & hematite & 0.1 \\
chatkalite & 0.8 & Cu-Cl (hydromelanothallite) & 2.9 & - & - \\
acanthite & 0.2 & magnetite & 0.03 & - & - \\
pyrite & 1.1 & K-feldspar & 0.04 & - & - \\
pypsum & 0.1 & digenite & 0.05 & - & - \\
castaingite & 0.1 & brochantite & 2.8 & - & - \\
apatite & 0.01 & sphalerite & 0.003 & - & - \\
rutile & 0.01 & chrysocolla & 0.2 & - & - \\
wolframite & 0.01 & - & - & - & - \\
chalcopyrite & 0.5 & - & - & - & - \\
sphalereite & 0.1 & - & - & - & - \\
emplectite & 0.1 & - & - & - & - \\
\hline
\end{tabular}

\subsection{Experimental Procedure}

Immediately before each test, the ground copper mineral was removed from the desiccator and added to the $200 \mathrm{~g}$ mixture of quartz and gold in a jacketed glass cell of $1 \mathrm{~L}$ capacity. The slurry was adjusted to $33.3 \%$ solid with double deionized water. Certified reagents, including ammonium hydroxide, sodium cyanide, lead nitrate and oxygen were used to condition the slurry. The cell cover has four openings that allow the insertion of electrodes, an agitator and a tube for adding air. The oxygen concentration was monitored by Oxi 340 oxygen meter and controlled by injecting air and oxygen into the slurry at various ratios. The temperature was controlled at $21{ }^{\circ} \mathrm{C}$ by circulating a mixture of water and ethylene glycol from a heat exchanger through the cell jacket. Agitation was accomplished with $255 \mathrm{~mm}$ Teflon paddles powered by a variable-speed electric motor. 
The Hunt leaching tests lasted between 24 and $48 \mathrm{~h}$, depending on the type of minerals. Ammonia was added as concentrated ammonium hydroxide solution (28\%-30\%), followed by NaCN. Calcium hydroxide was used to adjust the $\mathrm{pH}$ to above 11 . Both $\mathrm{NaCN}$ and $\mathrm{NH}_{3}$ in leaching were measured, on the filtrate, with ion selective electrodes (ISE) and adjusted after 1, 2, 4, 6, 24, $48 \mathrm{~h}$ of leaching. The $\mathrm{S} / \mathrm{L}$ separation was realized by either micro-filters or centrifuge. The solids taken during this procedure were returned to the reactor. The accuracy of ISE for both cyanide and ammonia are within $\pm 10 \%$. At the end of the tests, the pulps were filtered and the filter cakes were washed, dried, homogenized, sampled and analyzed for gold by fire assay in duplicates. The pregnant solutions were analyzed for $\mathrm{CNO}^{-}, \mathrm{CNS}^{-}, \mathrm{SO}_{4}{ }^{2-}$ and $\mathrm{Cu}_{\mathrm{tot}}$. The concentration of $\mathrm{CNO}^{-}$and $\mathrm{CNS}^{-}$and $\mathrm{SO}_{4}{ }^{2-}$ were determined by gradient elution HPLC (high performance liquid chromatography). The $\mathrm{Cu}$ contents were analyzed by ICP-AES (inductively coupled plasma atomic emission spectrometry). Because of interferences encountered by direct analysis of solution with Atomic Adsorption Spectroscopy, the liquid samples were analyzed for gold content using the fire assay.

For cyanidation tests, free cyanide was determined by titration with silver nitrate using rhodamine as an indicator. For the free cyanide concentration, the controlled value was a time weighted average obtained by the summation of the average content values $\left(\mathrm{C}_{\mathrm{i}}\right)$ within the sampling interval multiplied by the length of sampling interval $\left(\mathrm{t}_{\mathrm{i}}\right)$ divided by the total time $(\mathrm{t})$, i.e., the free cyanide concentration $=\left(\sum\left(\mathrm{C}_{\mathrm{i}} \times \mathrm{t}_{\mathrm{i}}\right) / \mathrm{t}\right)$. The variation of the realized average free cyanide concentration relative to the target free cyanide concentration was within $\pm 10 \%$ in this investigation. Free cyanide was also determined for the final leach and wash solutions. The calculation of cyanide consumption assumes $100 \%$ recycling of the leach solution.

\subsection{Analysis of Leached Residue and Gold Samples by XPS}

The XPS data were collected using a Kratos Axis Ultra XPS instrument equipped with monochromated $\mathrm{Al} \mathrm{K} \alpha$ radiation $(1487 \mathrm{eV})$. XPS data was collected using two modes. In the standard operating mode data was collected from an irradiated area approximately $700 \times 400 \mu \mathrm{m}$. For the djurleite experiment, the XPS was operated using the imaging mode and the data was collected from individual particles using a $220 \mu \mathrm{m}$ diameter aperture. Survey spectra were collected with a pass energy of $160 \mathrm{eV}$ and high resolution narrow region spectra were collected with a pass energy of $20 \mathrm{eV}$. The Kratos instrument has a novel magnetic confinement charge neutralization system. For the samples that experienced a build-up of positive charge, the neutralization settings were optimized to obtain the data with the highest quality. Absolute peak positions were calibrated using the $\mathrm{C} 1 \mathrm{~s}$ peak as $284.8 \mathrm{eV}$. Surface compositions were measured using established procedures. CasaXPS software was used to calculate surface concentrations and peak fit all the spectra. Surface concentrations were calculated using peak areas and sensitivity factors. Spectra were peak fit using $70 \%$ Lorentzian and $30 \%$ Gaussian shapes. The S 2p peaks were fit using spin orbit doublet peaks separated by $1.2 \mathrm{eV}$ and the $S 2 \mathrm{p} 1 / 2$ peak was constrained to half of the area of the $S 2 \mathrm{p} 3 / 2$ peak. 


\section{Results and Discussion}

\subsection{Djurleite-Bearing Synthetic Gold Ore}

Figure 1 illustrates the gold leaching kinetics in the presence of djurleite. With $6.1 \mathrm{~kg} / \mathrm{t} \mathrm{NaCN}$ added at the start of the experiment, the leaching curve reaches a plateau after two hours due to passivation of gold grains. The gold extraction slowly increases to a maximum of $51 \%$ in $48 \mathrm{~h}$. The leaching curve has a totally different profile with the control of free cyanide at $700 \mathrm{ppm} \mathrm{NaCN}$ (linear for the first $24 \mathrm{~h}$ ). Under these conditions, the curve is almost linear. This profile is also an indication of passivation by sulphide, but the passivation is less severe. The overall gold extraction reached $95.8 \%$ in $48 \mathrm{~h}$. The addition of lead nitrate alleviated the passivation and enhanced the gold leaching kinetics. Over $95 \%$ of gold was leached within $24 \mathrm{~h}$ and the extraction was complete $(99.7 \%)$ in $48 \mathrm{~h}$. The cyanide consumption was reduced from 6.5 to $5.8 \mathrm{~kg} / \mathrm{t}$ due to lead nitrate addition.

Figure 1. Effect of $\mathrm{NaCN}$ concentration and lead nitrate on gold extraction in presence of djurleite; $0.3 \% \mathrm{Cu}, \mathrm{pH} 11,8$ ppm DO.

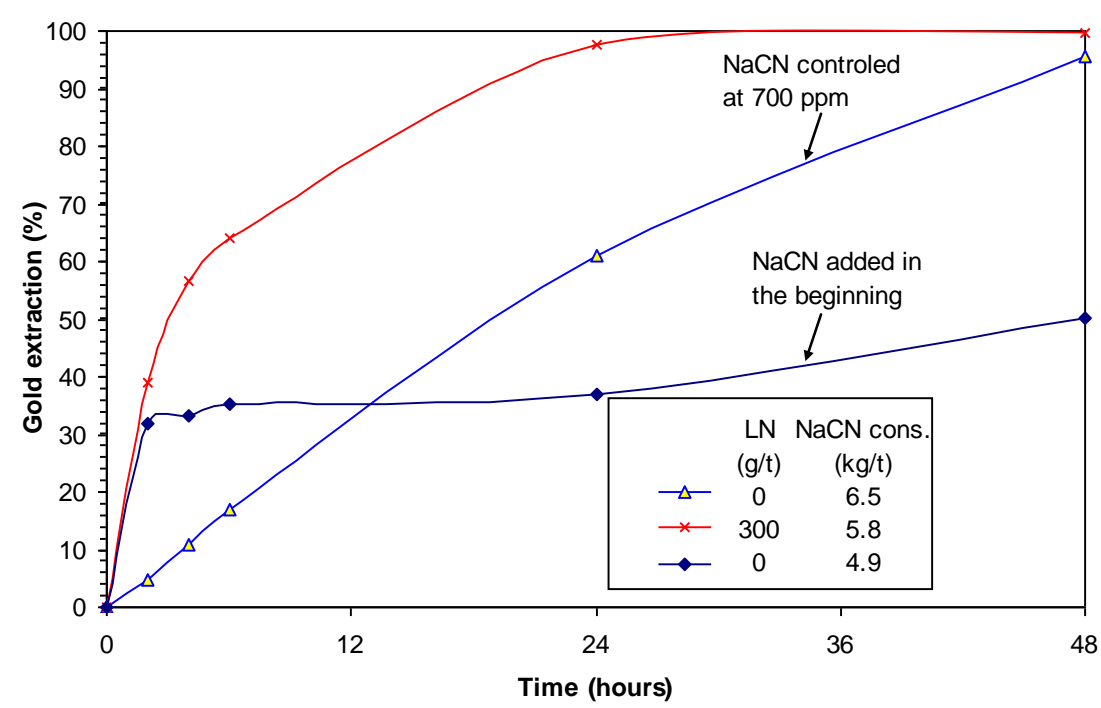

The dissolution of djurleite in a cyanide solution (using chalcocite as a proxy for djurleite) may be expressed as follow:

$$
\mathrm{Cu}_{2} \mathrm{~S}+7 \mathrm{CN}^{-}+0.5 \mathrm{O}_{2}+\mathrm{H}_{2} \mathrm{O}=2 \mathrm{Cu}(\mathrm{CN})_{3}{ }^{2-}+\mathrm{CNS}^{-}+2 \mathrm{OH}^{-}
$$

An XPS analysis of the gold surface identified various compounds $(\mathrm{Cu} / \mathrm{Ag}$ oxides, $\mathrm{Cu}(\mathrm{I})$ cyanide and sulphide). By adding lead nitrate, the amount of $\mathrm{Cu}(\mathrm{I})$ cyanide was reduced. In addition, the sulphide disappeared and lead oxide and hydroxide precipitated. These findings are in line with previous experimental results identifying lead compounds at the surface of gold [10]. The formation of these compounds reduced the passivation of gold.

The effect of ammonia was investigated using $350 \mathrm{ppm}, 500 \mathrm{ppm}$ and $700 \mathrm{ppm}$ ammonia with $400 \mathrm{ppm} \mathrm{NaCN}$. The leaching rate in the final six hours remained low under all conditions (Figure 2). The fastest leaching rate was achieved with $350 \mathrm{ppm}$ ammonia. However, the passivation of gold occurred after $24 \mathrm{~h}$ to level the extraction of gold at $88.5 \%$. High concentration of ammonia is detrimental for gold extraction after $24 \mathrm{~h}$. With $500 \mathrm{ppm}$ and $700 \mathrm{ppm} \mathrm{NH}$, the gold extraction 
approached completion (>99\%) within 48 hours. The associated cyanide consumptions were 2.3 and $2.6 \mathrm{~kg} / \mathrm{t} \mathrm{NaCN}$. The copper concentration did not vary much and remained in the range of $115 \mathrm{ppm}$. The results demonstrate that ammonia concentration is critical for producing a high overall gold extraction.

Figure 2. Effect of $\mathrm{NaCN}: \mathrm{NH}_{3}$ ratio on gold leaching in presence of djurleite; $0.3 \% \mathrm{Cu}$, 400 ppm NaCN, pH 11.5-11.8, 8 ppm DO.

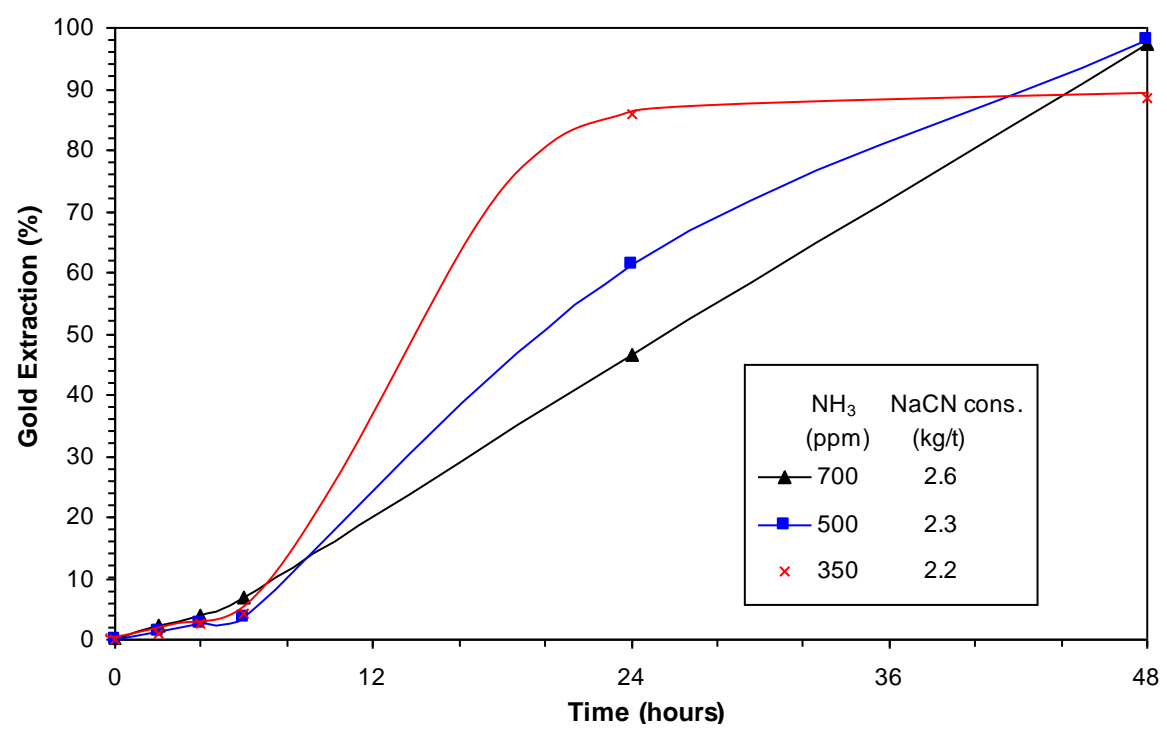

XPS analysis of leached djurleite samples indicated a significant amount of $\mathrm{CuS}$ and trace amount of $\mathrm{Cu}(\mathrm{II})$ on the mineral surface for the experiment using $350 \mathrm{ppm}$ ammonia while, on the djurleite surface leached with $700 \mathrm{ppm}$ ammonia, $\mathrm{CuS}$ was not significant, instead $\mathrm{Cu}(\mathrm{II})$ was found possibly as $\mathrm{Cu}(\mathrm{OH})_{2}$. The formation of $\mathrm{CuS}$, in the $350 \mathrm{ppm}$ ammonia experiment, indicates the formation of a metal deficient sulphide at the mineral surface and it appears that it has a chemical composition that is similar to covellite, $\left(\mathrm{Cu}_{3}\right)^{+}\left(\mathrm{S}_{2}\right)^{2-}\left(\mathrm{S}^{-}\right)$(Figure 3, [11-13]). Some $\mathrm{Cu}(\mathrm{I})$ sulphide, two $\mathrm{N}$ species (possibly ammonia and cyanide or their complexes) and polymerized sulphur were also found on the gold surfaces of the two leaching systems. Because of the similarities in the XPS spectra, it was not possible to identify the nature of the compounds that modified the leaching kinetics.

Oxygen oxidizes copper(I) to copper(II), which forms a copper amine in the presence of ammonia. Copper amine plays an important role in the oxidation of gold [9]. Meanwhile, the oxygen level may affect mineral oxidation and precipitation of copper. Therefore, tests were carried out at DO levels of 8,15 and $20 \mathrm{ppm}$ to determine the effect of dissolved oxygen concentration. Figure 4 shows that the gold extraction increased from $88.5 \%$ with a DO of 8 ppm to $99.7 \%$ when the DO increased to $15 \mathrm{ppm}$ or above. The change in oxygen concentrations, however, has no significant effects on the solution compositions.

The effect of $\mathrm{NaCN}$ concentration was investigated by changing the concentration of $\mathrm{NaCN}$ from 200 to $350 \mathrm{ppm}$ (Figure 5). The consumption of cyanide was reduced from $2.4 \mathrm{~kg} / \mathrm{t}$ at $350 \mathrm{ppm} \mathrm{NaCN}$ and $350 \mathrm{ppm}$ ammonia to $1.2 \mathrm{~kg} / \mathrm{t}$ at $200 \mathrm{ppm} \mathrm{NaCN}$ and $100 \mathrm{ppm}$ ammonia. The gold leaching kinetics decreased with the decrease in cyanide concentration but the overall gold extraction still reached $99.7 \%$ in $48 \mathrm{~h}$. The ammonia concentration has to be adjusted in tandem with the cyanide concentration to target the right ammonia/cyanide ratio. Surprisingly, the dissolved copper increased 
from about $130 \mathrm{ppm}$ to about $390 \mathrm{ppm}$ when the cyanide concentration was $250 \mathrm{ppm}$ or lower. The increase of copper cyanide species is likely to be the result of the decrease in copper hydroxide formation. Only $1.2 \mathrm{~kg} / \mathrm{t} \mathrm{NaCN}$ was required to have a complete gold dissolution using the Hunt process, compared to $5.8 \mathrm{~kg} / \mathrm{t}$ for cyanidation.

Figure 3. The S2p spectra from djurleite powder reacted in (a) $350 \mathrm{ppm}$ ammonia; and (b) 700 ppm ammonia.

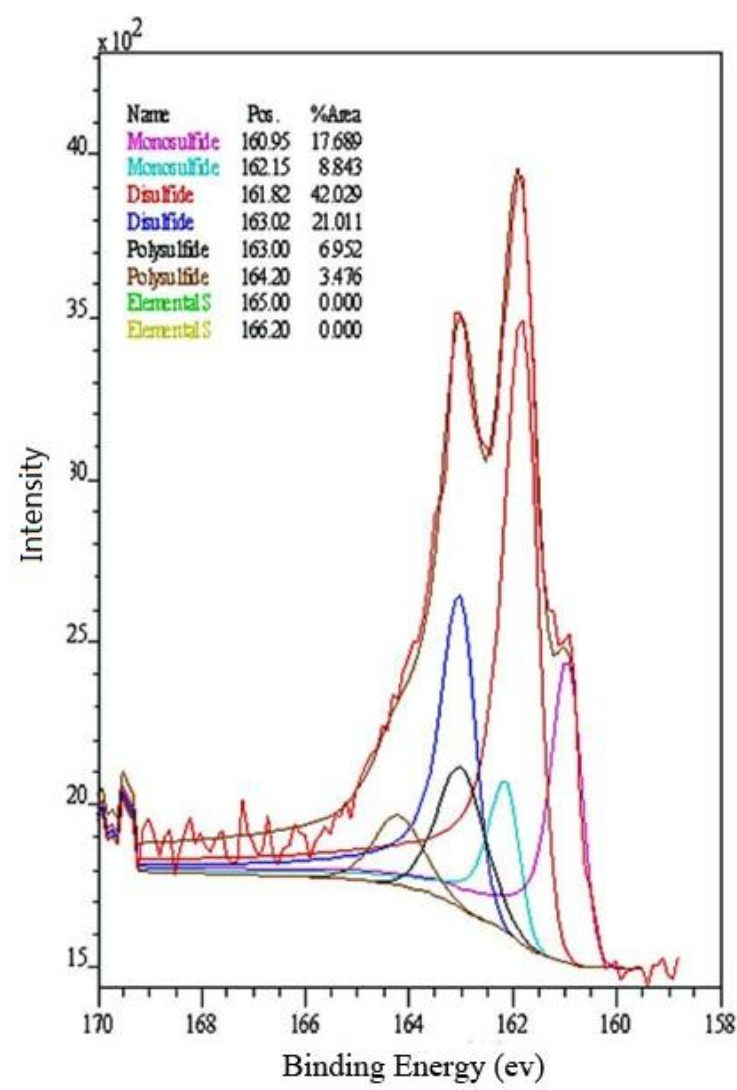

(a)

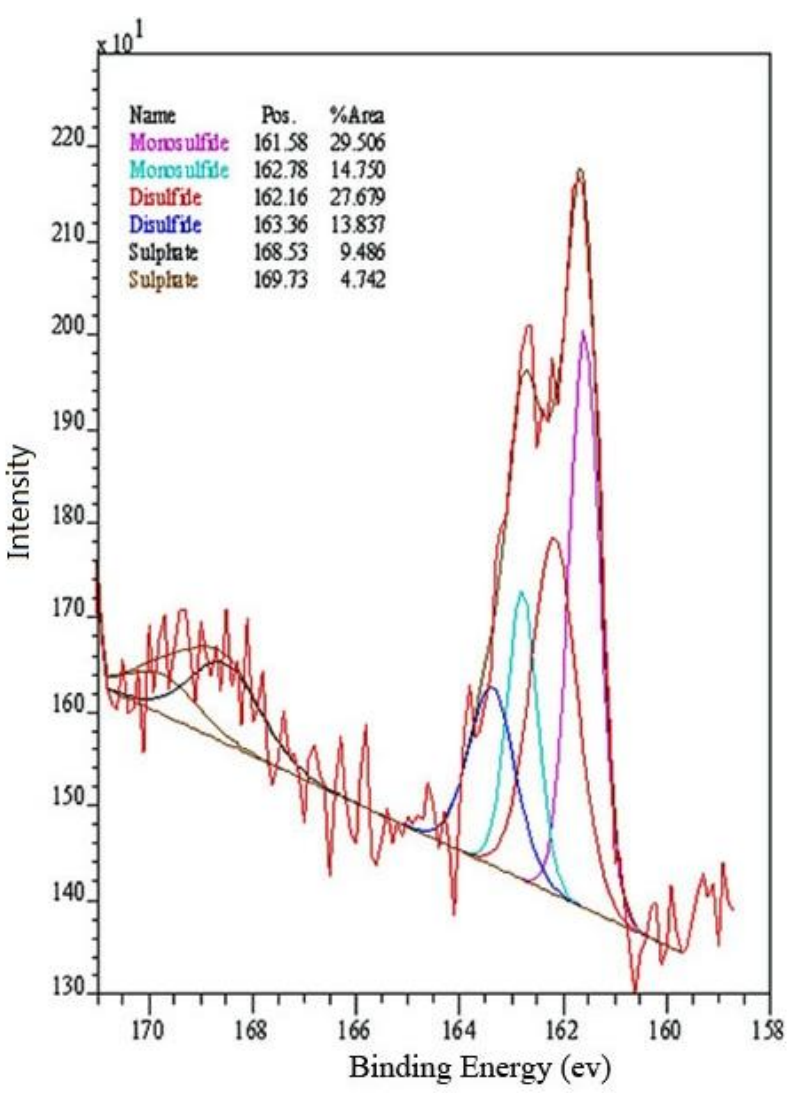

(b)

Figure 4. Effect of dissolved oxygen concentration of gold leaching in presence of djurleite; $0.3 \% \mathrm{Cu}, 400 \mathrm{ppm} \mathrm{NaCN}, 350 \mathrm{ppm} \mathrm{NH}_{3}, \mathrm{pH}$ from 11.5 to 11.8 .

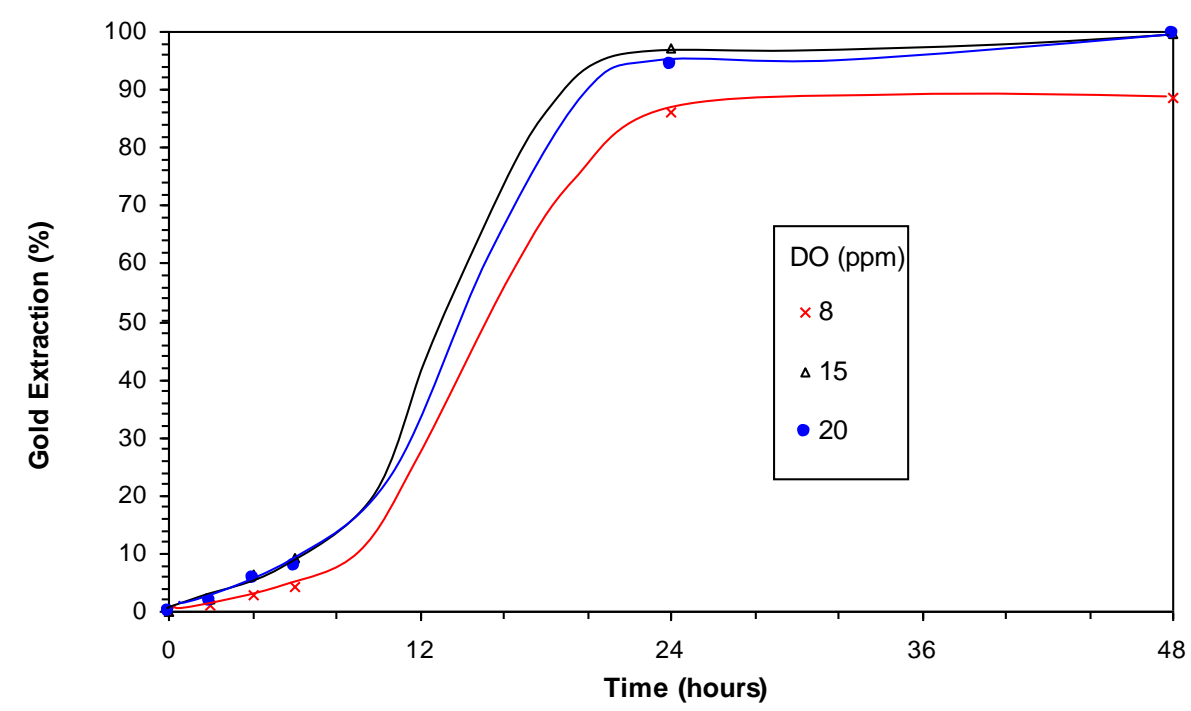


Figure 5. Effect of $\mathrm{NaCN}$ concentration on gold extraction in presence of djurleite; $0.3 \% \mathrm{Cu}, 15 \mathrm{ppm} \mathrm{DO}, \mathrm{pH}>11$.

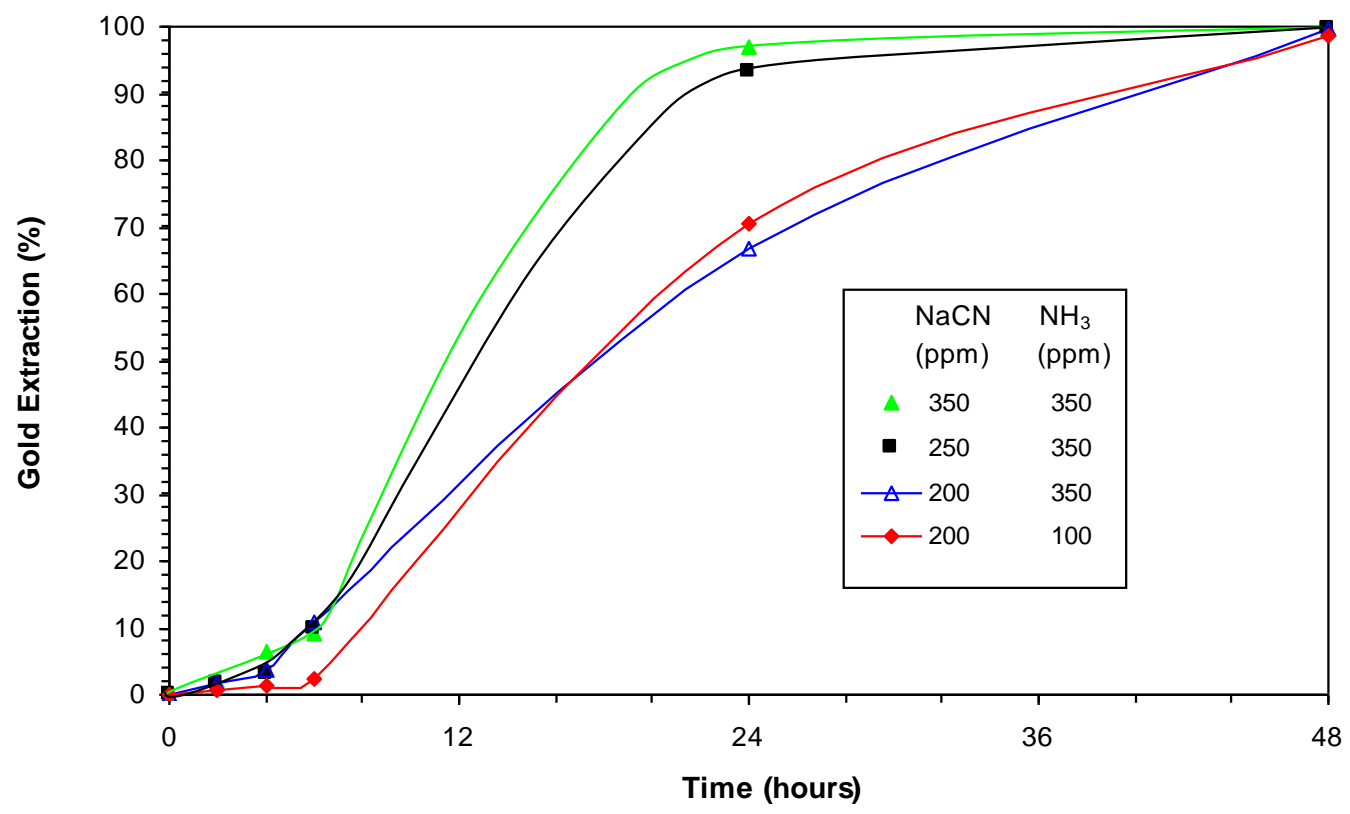

\subsection{Bornite-Bearing Synthetic Gold Ore}

The leaching kinetics profiles of experiments conducted at $800 \mathrm{ppm}$ and $1600 \mathrm{ppm} \mathrm{NaCN}$ show that passivation of gold occurs in absence of lead nitrate as the gold extraction remains less than $99 \%$ (Figure 6). Leaching with $800 \mathrm{ppm} \mathrm{NaCN}$ and $1600 \mathrm{ppm} \mathrm{NaCN}$ produced $85.4 \%$ and $96.1 \%$ respectively. The addition of $500 \mathrm{~g} / \mathrm{t}$ lead nitrate totally eliminated gold passivation and a complete extraction of gold was obtained within 6 hours even with only 500 ppm NaCN. Obviously, the dissolution of bornite undergoes a different mechanism in the presence of lead nitrate. The decrease of free cyanide concentration in leaching reduced the cyanide consumption from $6.1 \mathrm{~kg} / \mathrm{t}$ to $4.7 \mathrm{~kg} / \mathrm{t}$ $\mathrm{NaCN}$. The concentration of dissolved copper was reduced from $1370 \mathrm{ppm}$ to $1074 \mathrm{ppm}$. The dissolution of bornite in a cyanide solution may be expressed as:

$$
\mathrm{Cu}_{5} \mathrm{FeS}_{4}+19 \mathrm{CN}^{-}+2 \mathrm{O}_{2}+3 \mathrm{H}_{2} \mathrm{O}=5 \mathrm{Cu}(\mathrm{CN})_{3}{ }^{2-}+4 \mathrm{CNS}^{-}+\mathrm{FeOOH}+5 \mathrm{OH}^{-}
$$

Three tests were conducted with different $\mathrm{DO}, \mathrm{NaCN}$ and ammonia concentrations. In terms of gold extraction, these tests failed to increase gold extraction above $80 \%$ (Figure 7). Increasing the DO level from 8 to $20 \mathrm{ppm}$ did not introduce any significant enhancement of gold extraction at $350 \mathrm{ppm} \mathrm{NaCN}$. However, the increase of $\mathrm{NaCN}$ from $350 \mathrm{ppm}$ to $550 \mathrm{ppm}$ brought the extraction up from $46.1 \%$ to $65.5 \%$ in 48 hours. The consumption of cyanide was similar to that in the straight cyanidation $(2.0 \mathrm{~kg} / \mathrm{t}$ at $350 \mathrm{ppm}$ ). At $550 \mathrm{ppm} \mathrm{NaCN}$, the consumption increased to $3.2 \mathrm{~kg} / \mathrm{t}$. Gold dissolution at the initial stage of these Hunt tests was slower than straight cyanidation and it became faster after six hours. No significant reduction was observed on the dissolution of copper. In the straight cyanidation with 350 ppm NaCN, 560 ppm Cu was dissolved whereas, in these Hunt tests, the dissolved copper ranged from 439 to $818 \mathrm{ppm}$. 
Figure 6. Effect of $\mathrm{NaCN}$ concentration and lead nitrate addition on gold extraction in presence of bornite; $0.3 \% \mathrm{Cu}, 8 \mathrm{ppm} \mathrm{DO}, \mathrm{pH}>11$.

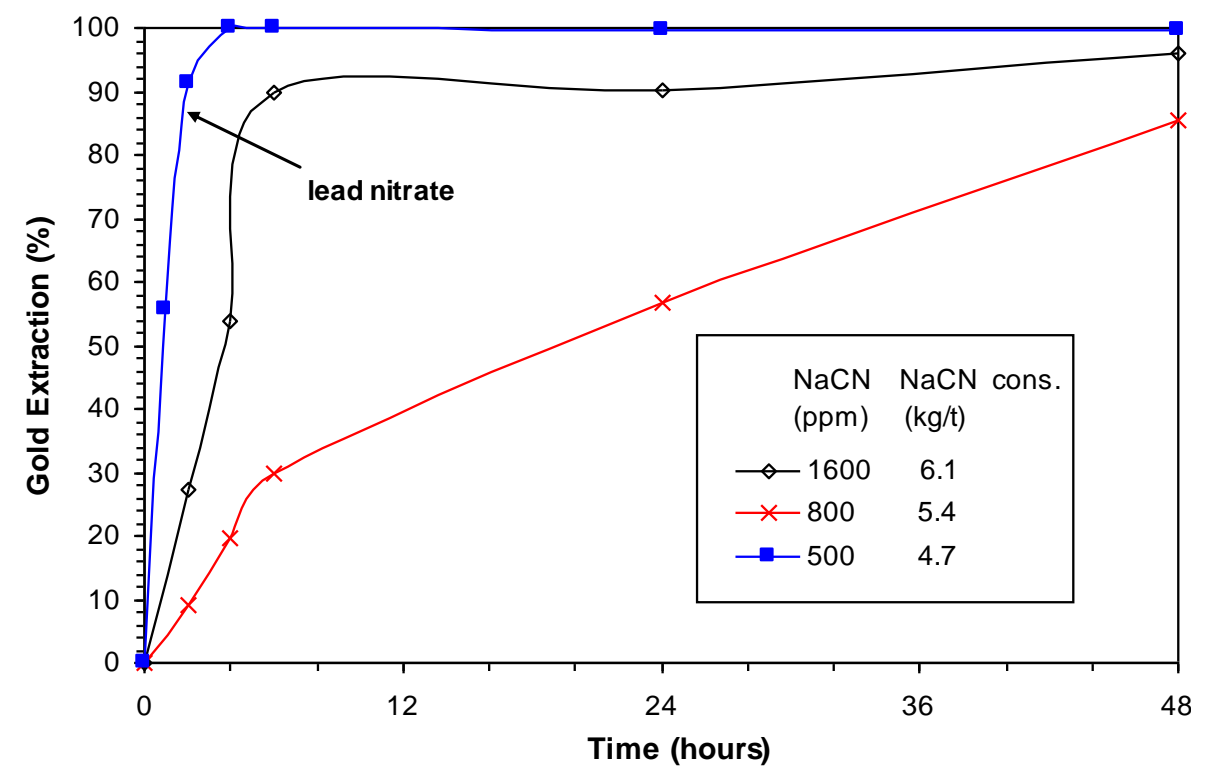

Figure 7. Hunt leaching test under typical Hunt conditions; $0.3 \% \mathrm{Cu}$ as bornite, $\mathrm{pH}>11$.

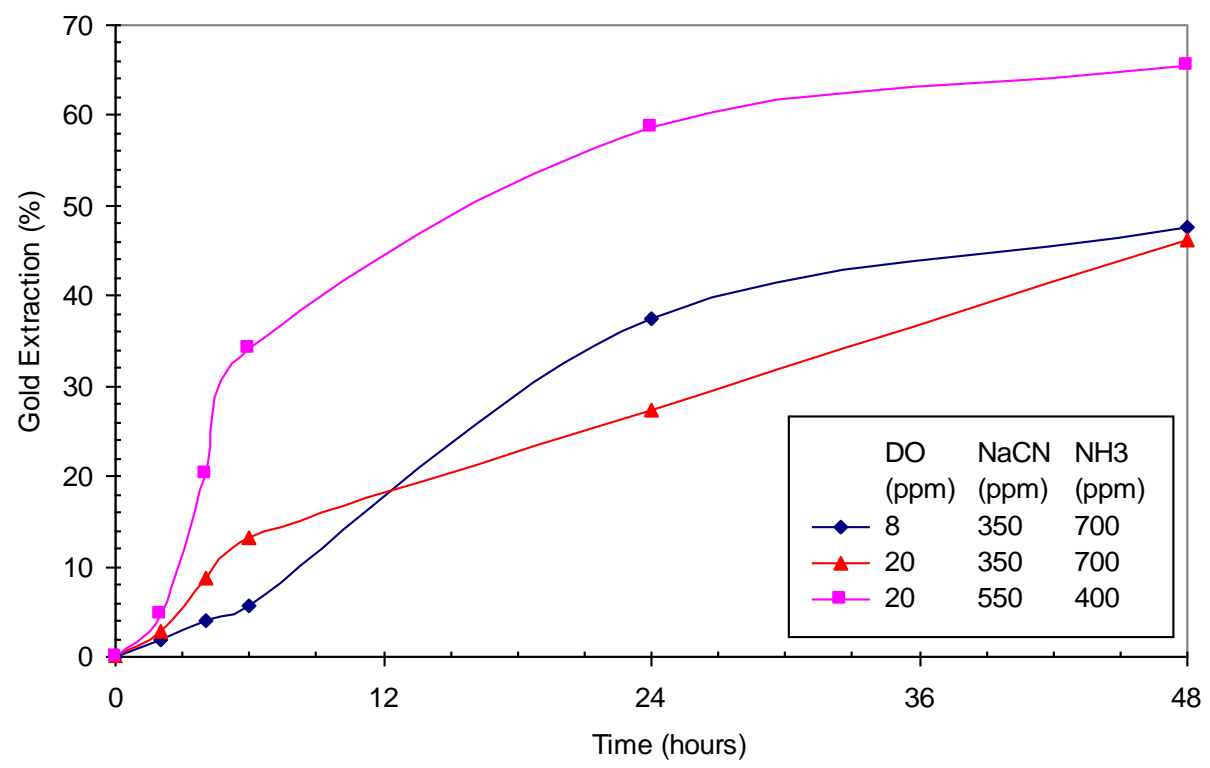

Tests were conducted at $400 \mathrm{ppm}$ and $1400 \mathrm{ppm}$ ammonia while maintaining the free cyanide at $850 \mathrm{ppm} \mathrm{NaCN}$. Figure 8 shows that gold extraction increased from $71 \%$ to $88 \%$ with cyanide consumption and 7.1 and $7.6 \mathrm{~kg} / \mathrm{t} \mathrm{NaCN}$. The results indicate that the Hunt leaching has limited efficiency for leaching gold in presence of bornite. This approach had limited effect on retarding the dissolution of copper and consequently the consumption of cyanide. The bornite consumes more cyanide than djurleite. However, due to the deficiency of $\mathrm{Fe}$ in bornite, the $\mathrm{FeOOH}$ formed is not enough to prevent further dissolution and oxidation of bornite. The high copper concentration indicates that the precipitation of copper is low. The volume of oxygen required to maintain the dissolved oxygen concentration is significantly larger for bornite than for djurleite. This is possibly due to the highly reductive nature of bornite (Equations 1 and 2). 
Figure 8. Hunt leaching tests at high cyanide concentration; $0.3 \% \mathrm{Cu}$ as bornite, $850 \mathrm{ppm}$ $\mathrm{NaCN}, \mathrm{pH} 11.7-11.9,8$ ppm DO.

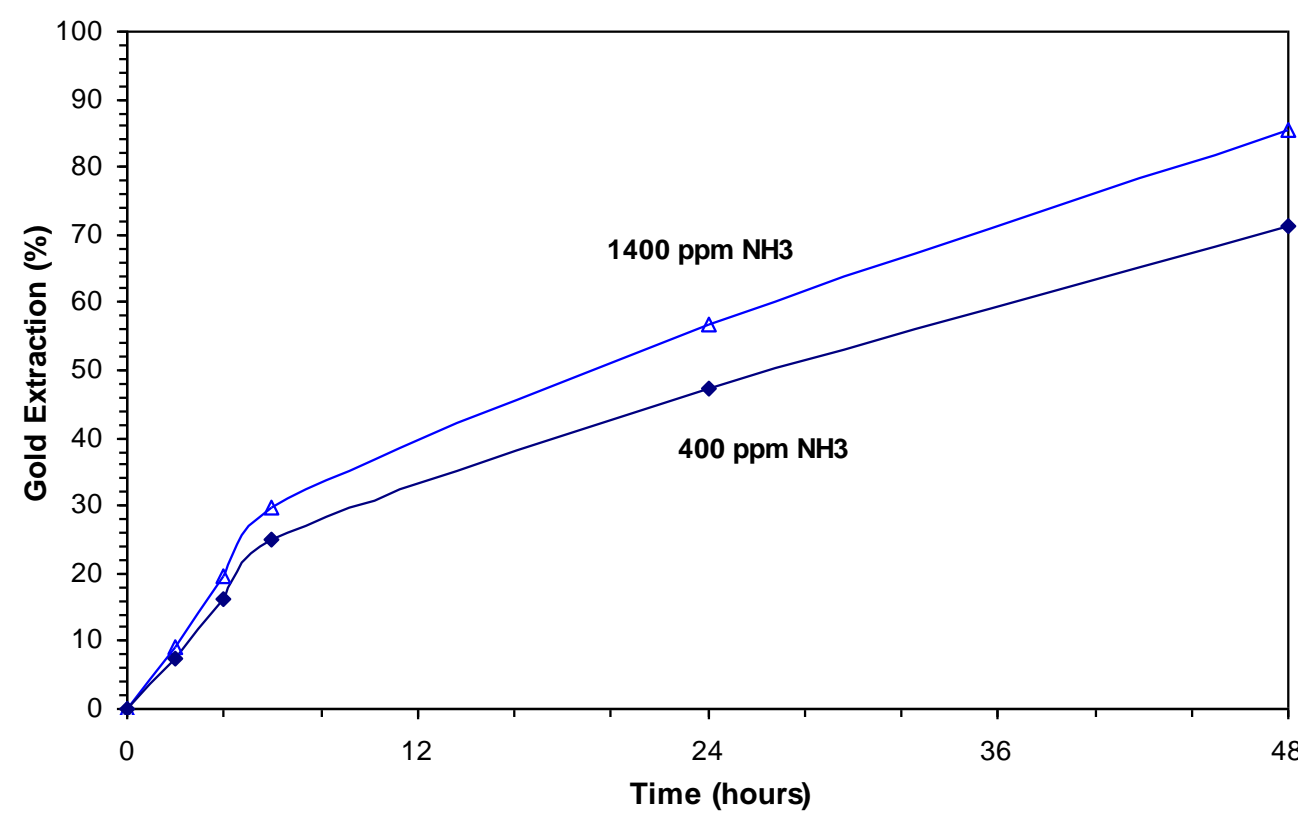

It was possible to improve the efficiency of ammonia-cyanide leaching by including a 4-hour pre-leach at pH 11 with the addition of $250 \mathrm{~g} / \mathrm{t}$ or $500 \mathrm{~g} / \mathrm{t}$ lead nitrate (Figure 9) prior to gold leaching. The concentration of cyanide and ammonia were controlled at $550 \mathrm{ppm}$. The cyanide consumption was reduced to $4.4 \mathrm{~kg} / \mathrm{t} \mathrm{NaCN}$. It is partly associated to a reduction of thiocyanate formed ( $50 \%$ reduction).

Figure 9. Effect of lead nitrate on gold leaching in presence of bornite; $0.3 \% \mathrm{Cu}, 550 \mathrm{ppm}$ $\mathrm{NaCN}, 400$ ppm NH $\mathrm{NH}_{3}$, pH 11.5-11.8.

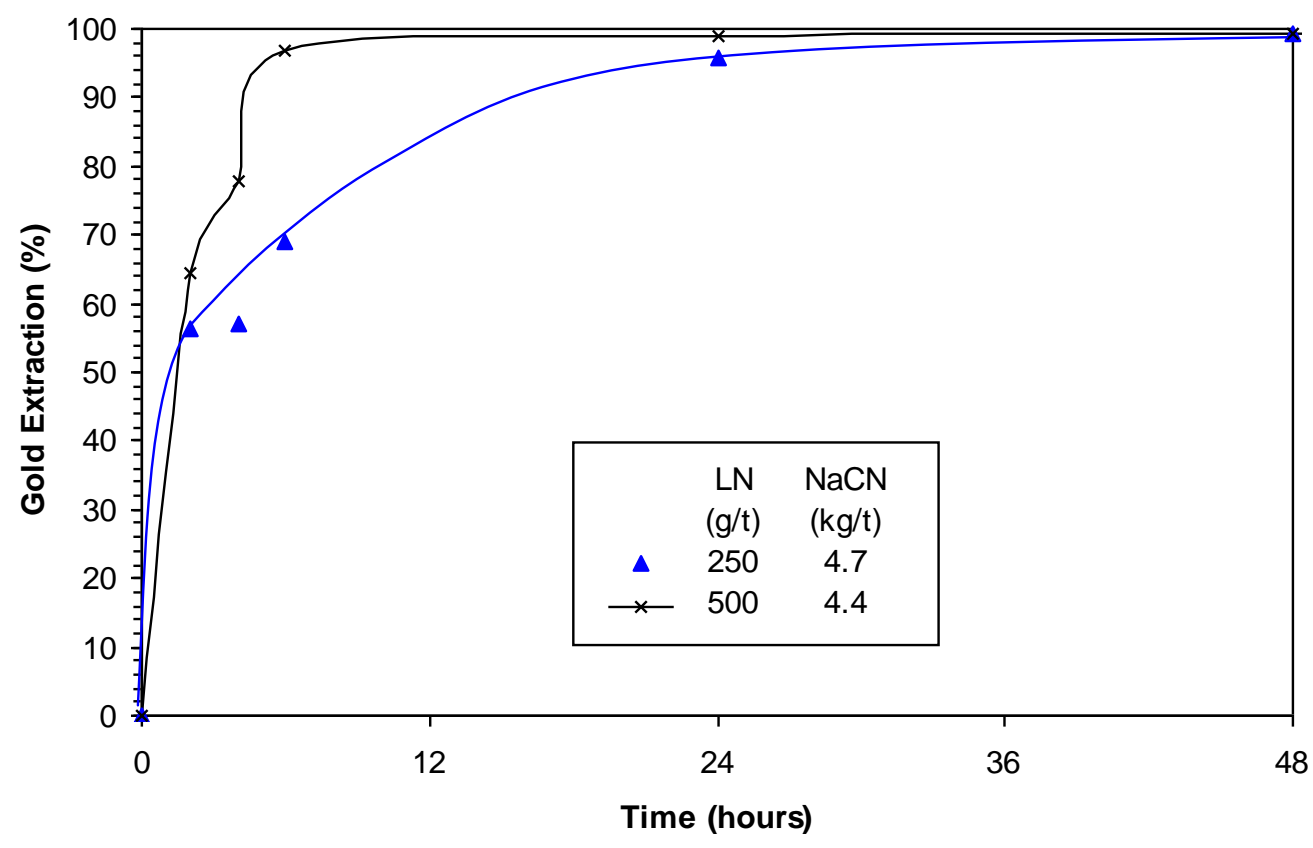


XPS study of the gold surface and bornite samples in the ammonia-cyanide leaching with or without lead nitrate showed several precipitated species. Gold was passivated by $\mathrm{Cu}(\mathrm{I})$ cyanide and possibly $\mathrm{Cu}(\mathrm{I})$ sulphide. With lead nitrate, the copper deposit on the surface was largely reduced. Instead, lead oxide and hydroxide appeared on the gold surface. Due to the decrease of copper precipitates, the gold dissolution is more active than that in the test without lead nitrate.

On the leached surface of bornite, the surface characteristics were found to be similar to djurleite. This change indicated that both copper and iron were dissolved. With lead nitrate, $\mathrm{Cu}(\mathrm{I})$ became $\mathrm{Cu}(\mathrm{I})$ sulphide and $\mathrm{Cu}(\mathrm{II})$ oxide and hydroxide at the surface of bornite. No $\mathrm{Cu}$-cyanide species were found. The metal deficient sulphide surface produced thiosulphate and polysulphide. Analysis of the leach solution showed the presence of sulphate and cyanate were not significantly modified by adding lead nitrate (32 to $54 \mathrm{ppm}$ for sulphate and 7 to $19 \mathrm{ppm}$ for cyanate). The effect of lead was to reduce the concentration of sulphide and copper on the gold surface. Lead also reported on gold as an oxide or hydroxide. Such a change explains the improved gold extraction rate.

\subsection{Chalcopyrite-Bearing Synthetic Gold Ore}

In the presence of chalcopyrite, the gold extraction in a cyanidation experiment with lead nitrate was $99.7 \%$ in four hours with $0.33 \mathrm{~kg} / \mathrm{t}$ of cyanide consumed (Figure 10). In absence of lead nitrate, the leaching kinetics were lower and the maximum extraction of gold was reached in $24 \mathrm{~h}$. At the same concentration, the reactivity of this pure chalcopyrite is lower than the one contained in Mouska ore [14]. However, it is comparable to the reactivity of chalcopyrite contained in Geant Dormant ore [15]. The addition of $500 \mathrm{ppm}$ ammonia improved gold leaching kinetics and overall extraction very close to the conventional cyanidation. The consumption of cyanide was slightly lower with ammonia $(0.25 \mathrm{~kg} / \mathrm{t} v s .0 .33 \mathrm{~kg} / \mathrm{t} \mathrm{NaCN})$.

The dissolution of chalcopyrite in a cyanide solution may be expresses as follow:

$$
\mathrm{CuFeS}_{2}+5 \mathrm{CN}^{-}+\mathrm{O}_{2}+\mathrm{H}_{2} \mathrm{O}=\mathrm{Cu}(\mathrm{CN})_{3}{ }^{2-}+2 \mathrm{CNS}^{-}+\mathrm{FeOOH}+\mathrm{OH}^{-}
$$

Figure 10. Effect of lead nitrate and ammonia on gold extraction in presence of chalcopyrite; $0.3 \% \mathrm{Cu}, 500$ ppm NaCN, 8 ppm DO.

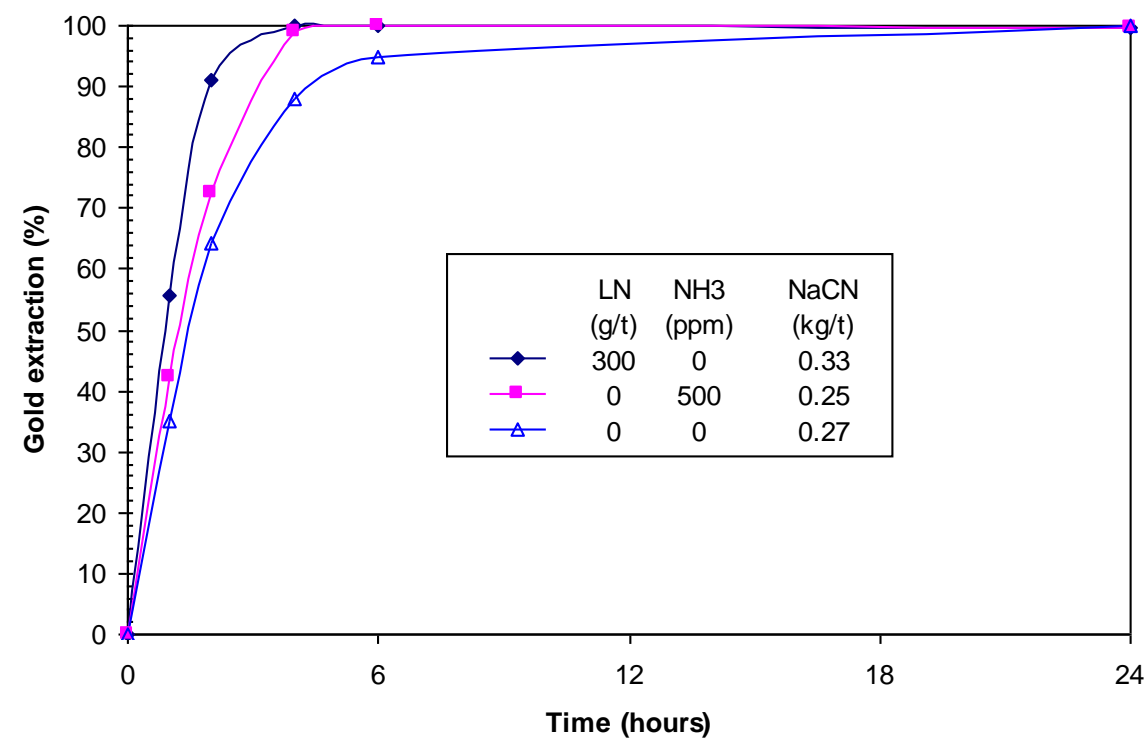


The XPS analysis indicated that the chalcopyrite powder was partially oxidized. The chalcopyrite surface contains $\mathrm{Cu}(\mathrm{I})$, an $\mathrm{Fe}(\mathrm{III})$ species, an $\mathrm{Fe}(\mathrm{II})-\mathrm{S}$ species, and a small amount of $\mathrm{Fe}$ in chalcopyrite. The sulphur data shows sulphur in chalcopyrite, along with sulphur in disulphide, polysulphide, and sulphate species. The oxygen data shows that oxide and hydroxide species are present. Some pristine chalcopyrite is detected and this suggests that the oxidized material coating particles is either very thin, or it may also occur as islands or some combination of both. This may explain the lower reactivity of chalcopyrite with cyanide.

Figure 11 shows that using lower cyanide and ammonia did not compromise gold extraction, which remained $>99 \%$. The gold leaching kinetics slightly decreased with the reduction of reagents concentration. The lowest consumption of cyanide recorded is $0.21 \mathrm{~kg} / \mathrm{t} \mathrm{NaCN}$. Comparison of actual leaching results with prior work on high purity chalcopyrite shows similarities in terms of low dissolution of copper [16].

Figure 11. Effect of cyanide and ammonia on gold extraction in presence of chalcopyrite; $0.3 \% \mathrm{Cu}, 8 \mathrm{ppm}$ DO.

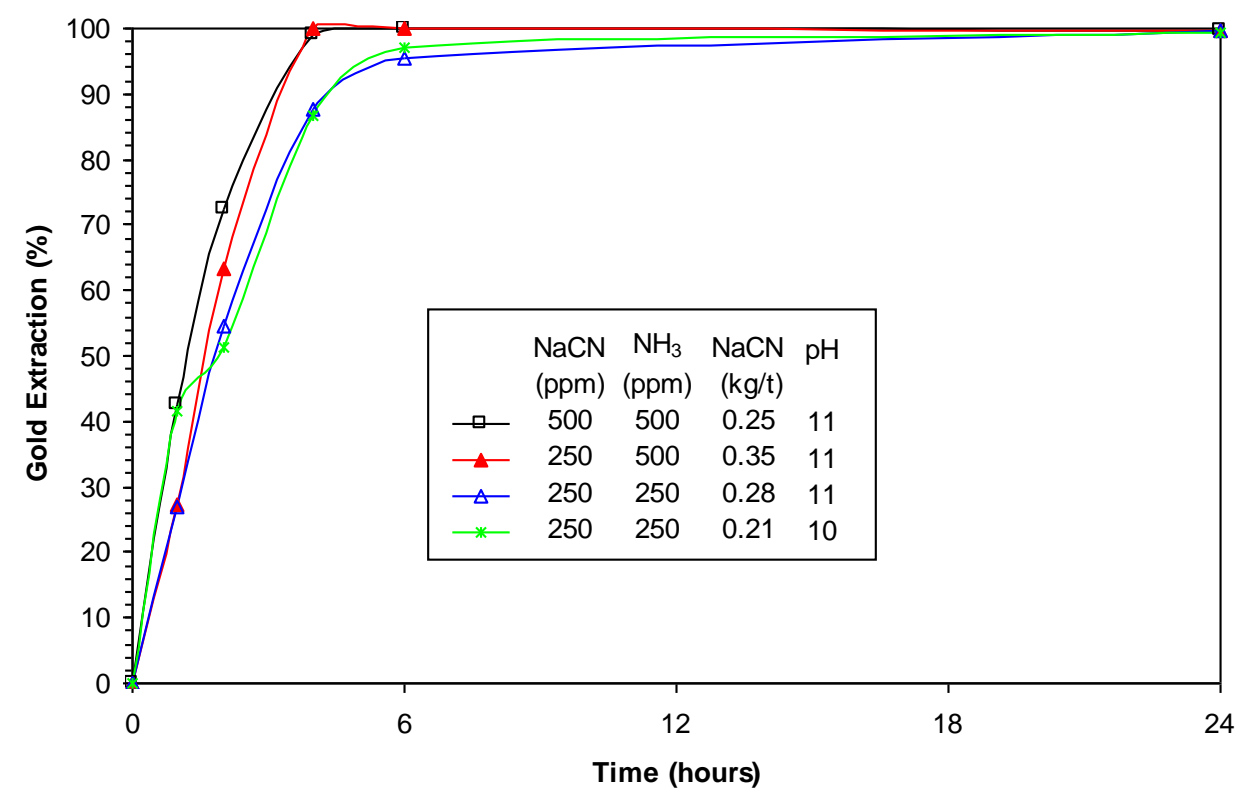

\section{Conclusions}

Efficient cyanidation of gold in the presence of djurleite and bornite had to be conducted with the addition of lead nitrate to avoid passivation of gold and excessive addition of cyanide. The ammonia-cyanide leaching of the slurry with djurleite proved to be more effective than cyanidation; producing a high gold extraction (99\%) while reducing the cyanide consumption from 5.8 to $1.2 \mathrm{~kg} / \mathrm{t}$ $\mathrm{NaCN}$. The lower cyanide consumption was associated to a significant reduction of copper dissolved. XPS surface analysis showed that the formation of $\mathrm{Cu}(\mathrm{OH})_{2}$ on djurleite grains inhibited its reaction with cyanide as well as minimizing the formation of sulphide on gold. Lead nitrate had to be added to the Hunt process to produce an efficient leaching of gold in presence of bornite. The cyanide consumption $(\sim 4.4 \mathrm{~kg} / \mathrm{t} \mathrm{NaCN})$ was not reduced by the addition of ammonia. Additional work is required to find out if the Hunt process performs better than cyanidation. Cyanidation of chalcopyrite showed a lower consumption of cyanide at $0.33 \mathrm{~kg} / \mathrm{t} \mathrm{NaCN}$. The addition of ammonia reduced the 
cyanide consumption to $0.21 \mathrm{~kg} / \mathrm{t} \mathrm{NaCN}$. No significant interferences were observed in gold leaching with a slurry containing chalcopyrite. Cyanidation and Hunt process demonstrated comparable leaching efficiency.

\section{Acknowledgments}

The authors would like to acknowledge Barrick Gold Corporation and Natural Resources Canada for the authorisation to publish this paper. We thank Tesfaye Negeri for the technical review and CANMET/MMSL analytical laboratory for the analyses.

\section{References}

1. Ruane, M. Gold recovery from the Paris mine tailings using ammoniacal cyanide Leachant. In Proceedings of Gold-Copper Ores (practical aspects): Colloquium, 4 July, 1991; Ammtec Pty. Ltd.: Balcatta, WA, Australia, 1991.

2. Costello, M.C. Summary of metallurgical testwork on the Akjoujt gold project. In Proceedings of Gold-Copper Ores (practical aspects): Colloquium, 4 July, 1991; Ammtec Pty. Ltd. Eds.; Ammtec Pty. Ltd.: Perth, WA, Australia, 1992.

3. La Brooy, S.R.; Komosa, T.; Muir, D.M. Selective leaching of gold from copper-gold ores using ammonia-cyanide mixtures. In Proceedings of 5th AusIMM Extractive Metallurgy Conference, Perth, Australia, 2-4 October 1991.

4. La Brooy, S.R. Copper-gold ores treatment options and status. In Randol Gold Forum, Vancouver'92; Randol International, Ed.; Randol International: Golden, CO, USA, 1992; pp. 173-177.

5. Drok, K.; Ritchie, I. An investigation of the selective leaching of gold over copper using ammoniacal cyanide. In Proceedings of World Gold'97, Singapore, 1-3 September 1997.

6. Vukcevic, S. The mechanism of gold extraction and copper precipitation from low grade ores in cyanide ammonia systems. Miner. Eng. 1997, 10, 309-326.

7. Jeffrey, M.I.; Linda, L.; Breuer, P.L.; Chu, C.K. A kinetic and electrochemical study of the ammonia cyanide process for leaching gold in solutions containing copper. Miner. Eng. 2002, 15, 1173-1180.

8. Muir, D.M. A review of the selective leaching of gold from oxidised copper-gold ores with ammonia-cyanide and new insights for plant control and operation. Miner. Eng. 2011, 24, 576-582.

9. Deschênes, G.; Guo, H.; Choi, Y. Preliminary investigation for the development of a leaching technology for gold extraction. In Proceedings of Symposium on Toward Clean Metallurgical Processing, Niagara Falls, Ontario, Canada, 30 September-3 October 2012; in press.

10. Deschênes, G.; Pratt, A.; Riveros, P.; Fulton, M. Reactions of gold and sulphide minerals in cyanide media. Miner. Metall. Process. 2002, 19, 169-177.

11. Pratt, A. XPS reference spectra for chalcocite. Division Report MMSL 2001-048 (TR); CANMET Mining and Mineral Sciences Laboratories, Natural Resources Canada, Ottawa, Canada, 2001.

12. Pratt, A. XPS reference spectra for covellite. Division Report MMSL 2002-010 (TR); CANMET Mining and Mineral Sciences Laboratories, Natural Resources Canada, 2002. 
13. Laajalehto, K.; Kartio, I.; Kaurila, T.; Laiho, T.; Suoninen, E. Investigation of copper sulfide surfaces using synchrotron radiation excited photoemission spectroscopy. In ECASIA 95: 6th European Conference on Applications of Surface and Interface Analysis; Mathieu, H.J., Reihl, B., Briggs, D., Eds.; Wiley: Chichester, UK, 1996.

14. Deschênes, G.; Prud'homme, P.J.H. Cyanidation of a copper-gold ore. Int. J. Miner. Process. 1997, 50, 127-41.

15. Deschênes, G.; Fulton, M. Improving cyanidation of a sulphide ore by using an efficient pre-leaching. In Proceedings of International Symposium on Recovery of Gold, Montreal, CIM General Annual Meeting; Laplante, A., Ed.; CMP/CIM: Ottawa, Canada, 2002; Volume 51, pp. 63-70.

16. Deschênes, G. CanmetMining, Ottawa, Canada. Unpublished work, 2012.

(C) 2012 by the authors; licensee MDPI, Basel, Switzerland. This article is an open access article distributed under the terms and conditions of the Creative Commons Attribution license (http://creativecommons.org/licenses/by/3.0/). 